\title{
Women becoming secondary school leaders:
}

Barriers, supports, and enablers

Cathy Wylie, Jo MacDonald, and Renee Tuifagalele 



\section{Women becoming secondary school leaders:}

Barriers, supports, and enablers

Cathy Wylie, Jo MacDonald, and Renee Tuifagalele

2020 
New Zealand Council for Educational Research P O Box 3237

Wellington

New Zealand

www.nzcer.org.nz

ISBN 978-1-99-004000-9

http://dx.doi.org/10.18296/rep.0005

(c) New Zealand Council for Educational Research, 2020 


\section{Contents}

1. Introduction 1

The overview questions 1

Our approach to leadership in this review 1

2. Research literature overview 2

3. The current state 3

Women remain under-represented in secondary principal roles 3

Women are particularly under-represented in coeducational school principal roles 3

The extent to which representation in other countries has improved varies 4

What do we know about women in other secondary school leadership roles?

4. Barriers 7

Gender framing of the principal's role as masculine $\quad 7$

Women underestimating their leadership skills and capacity $\quad 9$

Gendered family responsibilities and roles 9

Wāhine Mãori perspectives 9

Perspectives from Indigenous and ethnic minority women 10

5. Supports and enablers 11

Unbiased promotion and appointment processes 11

Active support and mentoring from principals and other school leaders 11

Creating more flexible principal roles 12

Women's own planning and initiative, and the availability of appropriate leadership professional development $\quad 12$

Support and encouragement from partners and other family 12

Wāhine Māori perspectives $\quad 13$

Perspectives from Indigenous and ethnic minority women 13

$\begin{array}{ll}\text { 6. Looking ahead } & 14\end{array}$

$\begin{array}{ll}\text { References } & 16\end{array}$

$\begin{array}{ll}\text { Appendices } & 19\end{array}$

Appendix A: Survey of secondary and composite schools, June 2020

Table

Table 1 Gender distribution of leadership roles in secondary schools (NZCER survey June 2020) 6

Figure

Figure 1 An overview of New Zealand data on women in secondary principal roles 



\section{Introduction}

The Post Primary Teachers' Association (PPTA) asked the New Zealand Council for Educational Research (NZCER) to provide an overview of the research literature on barriers and supports for women to succeed in secondary school leadership. The PPTA plan to use this review to help shape future work to address gender-based inequities. The Gender Pay Gap and Pay Equity Taskforce I Te Rōpū Mahi Rerekētanga Utu Ira Tangata me te Whakaōrite Utu is providing general momentum for such work.'

\section{The overview questions}

The following questions framed this overview of the available research:

- The current state-What do we know about women in secondary school leadership and their pathways to and through positional leadership roles?

- Barriers-What are the barriers to women being in positional leadership roles in secondary schools? Why are women not equally represented in leadership roles in secondary education?

- Supports and enablers-What policies and practices have been identified to better support women's pathways into and through positional leadership roles in secondary schools?

There are three sections in this report, one for each of the overarching questions.

\section{Our approach to leadership in this review}

The Teaching Council's Educational Leadership Strategy (Education Council, 2018a) takes a broad view of leadership, encompassing positional and non-positional leadership roles. The strategy defines educational leadership as “the practice of supporting others to make a positive difference to children's and young people's learning" (p. 8). We brought this broad lens to the review, but focused particularly on women in positional leadership roles, which are of most interest to the PPTA.

1 The taskforce is a partnership between the Ministry for Women and the State Services Commission: https://ssc.govt.nz/ourwork/the-gender-pay-gap-and-pay-equity/ 


\section{Research literature overview}

We looked for relevant research literature from the Aotearoa New Zealand context, as well as internationally. The NZCER library used the following databases: Education Research Complete, ERIC, A+ Education, PsycInfo, Index NZ, and Google Scholar, and looked for "grey literature" such as theses using NZResearch. We focused on research from the past 20 years, available in English. Reference lists in the literature found were also examined to find other relevant sources.

We looked for research that explored how the barriers and solutions differ for wāhine Māori, and Pacific women in Aotearoa New Zealand, and Indigenous and migrant groups internationally. We did not find any relating to Pacific women. We also did not find research focused on LGBTQI+ or disabled women in relation to secondary school leadership.

Much of the research looking at women's pathways to secondary school leadership and their experiences of barriers and supports was qualitative, based on interviews, focus groups, or small surveys. Some larger surveys were available, from England and Canada. Most of the research was focused on women who were principals, looking back on their journey and current observations. Some research focused on women in potential pathway positions, such as deputy principal, including their perceptions of the principal role and the bearing these perceptions had on their ambition to take on the principal role.

We cast our net widely and read 58 articles, book chapters, theses, conference papers, and newspaper articles relating to experiences in Aotearoa New Zealand, Australia, Canada, England, Hong Kong, Ireland, Israel, Spain, South Africa, Sweden, and the United States. Many of these sources are cited in this report. The material we do not directly cite provided additional context but was beyond the scope of the review (e.g., focused on women in business). 


\section{The current state}

\section{Women remain under-represented in secondary principal roles}

Women continue to be under-represented in secondary principal roles in relation to their numbers in the teaching workforce. Figure 1 gives a snapshot of the position of women at four points from 1991 to 2019. There has been a small improvement since 2004, but this is also consistent with an increase in the proportion of women secondary teachers. Over 15 years from 2004 to 2019, the proportion of women principals has increased by 5 percentage points, while the proportion of women among secondary teachers has increased by 4 percentage points.

The slow pace of change suggests that Aotearoa New Zealand is unlikely to achieve gender equality in secondary leadership in the foreseeable future unless there is deliberate attention paid to the development and support of women as leaders in secondary schools.

\section{FIGURE 1 An overview of New Zealand data on women in secondary principal roles}

- In 2019, women comprised $63 \%$ of the secondary ${ }^{2}$ teaching workforce, and $37 \%$ of secondary principals (Ministry of Education, 2020)

- In 2004, women comprised $59 \%$ of the secondary teaching workforce, and $32 \%$ of secondary principals (Ministry of Education, 2020)

- In 1995, women comprised 53\% of the secondary teaching workforce, and in $199625 \%$ of secondary principals (Graham \& Smith, 1999)

- In 1991, women comprised $51 \%$ of the secondary teaching workforce, and $19 \%$ of secondary principals (Court, 1994)

\section{Women are particularly under-represented in coeducational school principal roles}

Helen Pearce (2004) has provided a valuable history of women's access to leadership positions in coeducational and girls' secondary schools. The 1975 conference Education and the Equality of the Sexes held during International Women's Year called for a research project into the reasons for women's lack of promotion. This project, the Teacher Career and Promotion Study (Fenwick \& Whitcombe, 1982) found that women were more in favour of having women in senior positions than their male colleagues, with the principal a critical influence in promotion. This study recommended a more flexible promotion system and the active encouragement of women to use the promotion system. The Department of Education undertook to monitor promotion rates by annual publication of statistics (Pearce, 2004). However, by 1985, only five of 204 coeducational secondary schools had a female principal (Pearce, 2004, p. 81).

2 The secondary sector includes all secondary schools and composite schools (including Te Kura, the correspondence school).

3 Data obtained from Education Counts, teacher numbers interactive dashboard. 
PPTA action was needed, with government and the Human Rights Commission support leading to the then Secondary School Boards' Association reluctantly taking action. As part of an official Promotion of Women Review the association supported the setting up of joint review teams at every coeducational school to explore women's situation (Pearce, 2004). Encouragement and training were also given in PPTA women's seminars and other management seminars. The mandatory review at each school coupled with more encouragement and training led to a marked improvement in women applying for promotion (from $30 \%$ of applicants in 1986 to $36 \%$ of applicants in 1987), and appointment rates rising over that year from $37 \%$ in 1986 to $45 \%$ in 1987 (Pearce, 2004, p. 82). Women also increased their success in appointments to positions of responsibility, with more success as internal applicants.

The Promotion of Women Review was overtaken by the 1989 Tomorrow's Schools shift to school selfmanagement, and the Equal Employment Opportunity (EEO) sections in the State Sector Act 1988. Pearce (2004) described the EEO sections as having "much less force than the requirements of the Promotion of Women Review", and suggested that many schools abandoned the Review, citing the EEO (p. 83).

In 1991, just 7\% ${ }^{4}$ of principals of coeducational schools were women (Court, 1994). Marion Court's research showed that: $33 \%$ of deputy principals were women; $58 \%$ of assistant principals, second principals, or senior masters/mistresses were women; and $40 \%$ of the heads of department and senior teachers were women.

The 1995 figures for women secondary principals show a marked improvement: 13\% of principals of coeducational schools were women, and 47 of the then 77 women principals led girls' secondary schools (Graham \& Smith, 1999).

Helen Pearce's analysis ${ }^{5}$ of the gender of principals of coeducational secondary schools in 2014 showed a further increase: $22 \%$ were women (Pearce, 2015). There was considerable variation in the proportion of women principals across regions and school types. For example, only three of the 22 state-integrated coeducational secondary schools had women principals. There was a much higher proportion of women principals in the 36 state area schools: $44 \%$.

\section{The extent to which representation in other countries has improved varies}

Aotearoa New Zealand is not alone in its under-representation of women among secondary school principals. England has a similar system of school self-management, with individual or federation school boards employing principals. In 2018, $62 \%$ of the secondary teaching force were women, and $38 \%$ of headteachers (principals)-unchanged since 2010 (Morrison, 2018). Women made up 62\% of middle leadership roles, but less than their proportionate share of deputy and assistant head roles, which are the key pathway to the headteacher role. Women headteachers took longer to get to the role than their male colleagues. The same article notes that $9 \%$ of secondary headteachers were from ethnic minorities, compared with $17 \%$ of secondary teachers (Morrison, 2018). At the rate of improvement since 2001, Fuller (2017) concluded that it would take until 2040 to match the proportion of women principals with the proportion of women teachers in secondary schools in England.

Wales is one region which has seen marked improvement in the equitable representation of women among secondary school headteachers: from 17\% in 2004 to 32\% in 2012 ("Women Secondary School Head Teachers Double in Wales in Eight Years," 2012). Reasons suggested in the BBC story giving this information included a better gender balance in middle leadership, women developing stronger skillsets and more

4 Note that Pearce (2004) states this number as 13 out of 221, which is $6 \%$.

5 This document was provided to us by the PPTA. A note from the author says: "The information on which these statistics are based was derived from the Secondary Schools Directory 2014 compiled by Tarawera High School and individual school websites when known changes had been made, so may not be completely accurate at the present time." This shows the difficulty in collating such data when it is not collected at a system level. 
confidence through middle leadership roles and more professional development, more family-friendly policies, greater awareness of the need for gender balance, and fewer old boys' networks.

New South Wales (NSW) has also seen a marked increase in women secondary principals, from $22 \%$ in 1998, to 48\% in 2018 (McGrath, 2019). While there were increases in the proportion of women secondary teachers as well, government-funded union-run gender equity programmes were seen as a key reason for the change by the NSW Secondary Principals Council president (Poole, n.d.). McGrath (2019) also notes the NSW Department of Education offered a range of support through the Women in Educational Leadership Network, the Springboard Women's Development Program, encouragement of women to take part in the NSW Leadership Academy program, and support for flexible work arrangements for women in leadership positions.

\section{What do we know about women in other secondary school leadership roles?}

National-level data on women in positional leadership roles other than the principal in Aotearoa New Zealand secondary schools is not readily available from the Ministry of Education. To get a snapshot of the numbers of women in these positional leadership roles, we added a short survey to the scope of this literature overview, designed with PPTA input. The survey (see Appendix A) asked about gender distribution (female, male, gender diverse) for all teaching staff, and across all school positional leadership roles. The online survey link was emailed to the 199 principals of secondary and area schools who are PPTA members. Because ethnicity data is best collected from individuals themselves, we did not ask principals for this.

The survey administration was delayed due to the COVID-19 lockdown and was sent to principals in early June. We had 60 responses-a response rate of $30 \%$-from a range of schools in terms of school characteristics. The response rate was likely impacted by the COVID-19 context. Although a small number, the sample is fairly representative of the overall population of secondary and composite schools in relation to decile, location, and gender of students. Compared with the overall national population (i.e., all secondary and composite schools in the country), we have data from:

- fewer low decile schools (21\% of our sample, compared with $31 \%$ of the overall population) and more mid-decile schools ( $50 \%$ compared with $38 \%$ of the overall population)

- fewer rural schools (6\% compared with $13 \%$ of the overall population) and more schools in minor urban areas ( $27 \%$ compared with $18 \%$ of the overall population)

- a similar proportion of co-educational, girls', and boys' schools.

Of note is that more schools responding to our survey had a female principal: Table 1 shows that over half $(56 \%)$ of principals from the responding schools were female, compared with $37 \%$ of the overall population of secondary schools (reported above, from Ministry of Education data). We surmise this is likely to be because female principals were more likely than male principals to respond to a survey about women in secondary school leadership. ${ }^{6}$ We do not have national data to compare with our sample for other roles, but overall the percentage of female teaching staff (66\%) in schools responding to our survey is close to the national figure of $63 \%$.

Given the small sample size we have not done statistical tests on the data. For each role, we looked at the difference in percentage points from the overall teaching staff for the schools that responded (66\% female, and $34 \%$ male). We highlight the following:

- most SENCO and other Special Education leaders (87\%), and heads of guidance or counselling (80\%) are women. These roles show the highest over-representation of women, with a percentage point difference of more than 14 from the proportion of female teachers overall.

6 Women comprise $39 \%$ of principals belonging to the PPTA. 
- a higher proportion of men than the proportion of male teachers in the schools responding are in senior leadership roles (principal, deputy principal, assistant principal). These roles have some over-representation of men, with a percentage point difference of 7-10 from the proportion of male teachers overall.

- women and men are in middle leadership roles (i.e., heads of department, teacher in charge, dean) in the same proportions as female and male teachers overall.

Table 1 shows the gender distribution of leadership roles in the schools responding.

TABLE 1 Gender distribution of leadership roles in secondary schools (NZCER survey June 2020)

$\begin{array}{lcc}\text { Role } & \text { Female (\%) } & \text { Male (\%) } \\ \text { All teaching staff }(n=53) & 66 & 34 \\ \text { Principal }(n=55) & 56 & 44 \\ \text { Deputy principal }(n=53) & 59 & 41 \\ \text { Assistant principal }(n=31) & 57 & 43 \\ \text { Head of department/learning area/faculty }(n=54) & 68 & 32 \\ \text { Teacher in charge }(n=40) & 65 & 38 \\ \text { Dean ( } n=51) & 62 & 12 \\ \text { SENCO ( } n=53) & 87 & 20 \\ \text { Head of guidance/counselling }(n=50) & 80 & 29 \\ \text { Specialist classroom teacher }(n=51) & 71 & 28 \\ \text { Other leadership roles }(n=35) & 72 & \end{array}$

Note: Due to rounding, percentages do not all sum to 100. Only nine schools provided data about associate principals, so this data has not been included in the table. Seven gender-diverse teaching staff were recorded, with four in leadership roles. Due to these small numbers, they are not included in the table.

We also did some additional analysis of data from the latest NZCER national survey of secondary schools, undertaken in 2018 (Bonne \& MacDonald, 2019). We looked for associations between gender and teachers' responses to other questions including role in the school, workload and job satisfaction, career plans for the next 5 years, and interest in being a principal. There was just one statistically significant association, that female teachers responding to the survey were more likely than male teachers to be careers advisors or transition teachers.

We also looked for any associations in the national survey data between gender and principals' responses to other questions, including support for the role, professional contact with other principals, stress levels, and what they would change about their work. There were two statistically significant associations.

- Female principals $(92 \%)$ were more likely than male principals $(78 \%)$ to say they wanted more time to focus on educational leadership, when asked what they would change about their work.

- Female principals (17\%) were more likely than male principals (10\%) to indicate they had "other" support in the role, beyond the categories included in the question: SPANZ, PPTA, private consultants, and postgraduate study. 


\section{Barriers}

The barriers to women progressing into secondary school principalship found in the research material fall into three main groups.

\section{Gender framing of the principal's role as masculine}

Key themes:

- Discrimination arising from this framing in relation to job criteria, selection, and development opportunities.

- Homosociability (being comfortable with those most like you) affecting employment decisions.

- Male-oriented networks, "old boys' clubs", and male-dominated governing bodies and school leadership teams lead to women having to work harder than men to get leadership positions, and their having fewer opportunities for mentoring and support.

\section{Women underestimating their leadership skills, and capacity}

Key theme:

- Women are more likely to believe they must meet all criteria before applying for a job.

\section{Gendered family responsibilities and roles}

Key themes:

- Motherhood means the leadership journey can take longer, or that women get "off the ladder" in terms of career pathways. It can also mean that others view maternal responsibilities as a limitation to leadership development, and that they overlook women who may be on maternity leave or who have taken longer than men to progress through leadership roles.

- Women in heterosexual relationships do more in terms of childcare and domestic labour than male partners, which clashes with the time demands of school leadership.

- A man's employment more often decides on family location and housing than a woman's employment, making it harder for a woman in a heterosexual relationship to relocate to take a school leadership role.

The next section discusses each of these barriers in more detail, and considers literature relating to wāhine Māori, Indigenous women from outside of Aotearoa New Zealand, and ethnic minority women.

\section{Gender framing of the principal's role as masculine}

A significant and multi-faceted theme in the literature is the framing of the principal's role as masculine. How this role is framed and understood has advantaged men where the role is seen as primarily managerial and hierarchical, even autocratic or "tough" (Smith, 2011a). Portrayed this way, the role may also be less attractive to women, who often want to stay connected with students, provide educational leadership, and work in more collaborative ways (Coleman, 2007; Helterbran \& Rieg, 2004; Oplatka \& Tamir, 
2009; Smith, 2011a). However, it is this educational leadership aspect and working more collaboratively that has come to the fore in recent years in research about effective school leadership, and the development of the Teaching Council's Leadership Strategy and its Educational Leadership Capability Framework (Education Council, 2018b).

Conceptions of the pathway to principalship have disadvantaged women where management responsibilities such as timetabling or finances are seen as stepping stones to the principalship, in contrast to pastoral and curriculum leadership responsibilities (Court, 1994; Graham \& Smith, 1999), which have more often interested women in secondary schools. A parallel source of disadvantage for women's promotion is found in universities, where women's teaching and pastoral roles are "over demanded and under-rewarded" (Brower \& James, 2020).

While job advertisements, job specifications, and interview processes can appear gender neutral, bias towards appointing males is evident. In Aotearoa New Zealand, school boards of trustees have shown a bias towards male applicants in their final decision, with men six times more likely than women to get a principal's job in primary schools (Brooking et al., 2003). Blackmore and Thomson (2006) note that appointment panels may discuss candidate suitability beyond reference to the stated criteria, such as family responsibilities for women. Applicant experience in sports coaching has been a bias in New Zealand (Brooking et al., 2003), and evident in the United States: 65\% of male high school principals had been team coaches (Kruse \& Krumm, 2016).

Bias towards men is not necessarily conscious, but it reflects perceptions of the principal role. Blackmore et al. (2006) note that principal selection processes can create "normal" principal identities that are not aligned with equity and diversity policies and innovative practices. There can be a pattern of "reproduction of the known" where the selected applicant for the principal role is someone who is already known by the panellists (Blackmore et al., 2006, p. 7). This also reflects "homosociability", where decision makers feel more comfortable with someone who is like themselves (Alberta Teachers' Association, 2020; Coleman, 2012; Fitzgerald, 2003b; Spiller, 2013). Fuller (2017) notes that more diversity is needed in governing bodies and school leadership teams to counter this bias. Kruse and Krumm (2016) cite a 2011 study of a US district where principals approached or encouraged more males and those of their own ethnicity to become principals, regardless of women's prior leadership experience and positive leadership ratings. Lack of mentorship and female role models are cited in Uwamahoro (2011), Jean-Marie (2013), Mestry and Schmidt (2012), and Robinson et al. (2019).

Attitudes that count against women seeking to become principals include "cultural scripts that identify feminine attributes as contributing to ineffective leadership" (Oplatka \& Tamir, 2009, p. 219). Half the respondents to a survey of senior leadership teams in English schools thought that men were stereotypically seen as better leaders than women (McNamara et al., 2010).

Some males believe that women cannot discipline older students, especially male students (Helterbran \& Rieg, 2004), or boys of any age (Brooking et al., 2003). Some give priority to providing male role models for boys from single-parent families (Watterston, 2010). Faith or culture can also give primacy to men in roles of authority (Jean-Marie, 2013; Mestry \& Schmidt, 2012; Robinson et al., 2019; Watterston, 2010). Discriminatory attitudes also exist among teaching colleagues, students, and parents (Fuller et al., 2015; Kruse \& Krumm, 2016). Gender stereotyping also plays a role, with a different lens on the same behaviour, e.g., seeing women as aggressive rather than strong (Watterston, 2010). Watterston and Kise (2019) cited an American study with a large sample of business leaders that highlighted how gender stereotypes create three key predicaments for women: extreme perceptions; women leaders are perceived as too soft or too tough; a high-competence threshold; and a tendency to be seen as competent or likable, but not both (p. 45). 
The 2019 Alberta Teachers Association survey of its members found that women were much more likely than men to think that men had a greater chance of advancement (59\% of women compared with $26 \%$ of men), citing males being over-represented in leadership, men being treated with more respect, the "old boys club", and beliefs that women were limited by their maternal responsibilities or because of pregnancy (Alberta Teachers' Association, 2020). Mentorship opportunities were more available to men, particularly if networking opportunities were informal, centred around male activities, or if men dominated in formal meetings. Male-oriented meetings and "old boys' clubs" are also cited by Gallagher (2017), Helterbran and Rieg (2004), and Mortimer and Edwards (2018).

\section{Women underestimating their leadership skills and capacity}

Women more often believe they must "tick all the boxes" of job descriptions before they apply, unlike men (Watterston, 2010; Watterston \& Kise, 2019). Kruse and Krumm (2016) cite a 2008 study finding that $61 \%$ of women waited to apply for school leadership roles until they had met all the qualification requirements and their children were grown, compared with $5 \%$ of men. Coleman (2007) found that a quarter of women headteachers had never planned to become a head, compared with "a much smaller proportion of men"7 (p. 387).

Principal workload and the sense that it is a "24/7" responsibility can be off-putting for women, particularly if their deputy principal or assistant principal role has high workload and stress (EltonChalcraft et al., 2018; Graham \& Smith, 1999; Guihen, 2019; Oplatka \& Tamir, 2009).

\section{Gendered family responsibilities and roles}

For many women, motherhood can take priority over a linear progression from teaching to school leadership roles, and particularly the principal role if that is seen as all-consuming in terms of time and energy. Mortimer and Edwards (2018) talk of women's "complex, non-linear" careers, which can disadvantage women if those making decisions on developing or appointing leaders see careers in linear terms. Cuneen and Harford (2015) note the importance of schools providing childcare friendly practices.

Women can also be disadvantaged if the domestic work in their household is not shared (Alberta Teachers' Association, 2020). Coleman (2007) found that over $40 \%$ of English female headteachers took more responsibility than their partners for domestic affairs, compared with $2 \%$ of their male counterparts.

Difficulties of relocating to take a school leadership role are experienced more by women than men (Hunt Brown, 2004; Mortimer \& Edwards, 2018), when priority is given to male partners' jobs and location.

\section{Wāhine Māori perspectives}

The literature about barriers for Māori women in school leadership is very limited. The only text we read by a Māori researcher was a Master's thesis by Trudy Taukamo (2011). Tanya Fitzgerald, a Pākehā woman, has written about Indigenous women in leadership, with a particular focus on Māori. She acknowledges that these discourses are outside of her own "territory" as a Pākehā academic, and reiterates that the challenges and experiences of Māori women school leaders cannot be understood or explained against the similarities and differences of Pākehā women leaders (Fitzgerald, 2003b). Fitzgerald suggests that there is a colonising assumption that Māori leadership is a predominantly male and individualistic space, and that Māori women are subordinate to men, when in fact this is not true (Fitzgerald, 2003b).

7 The proportion of men who never planned to become a head is not provided in the article. 
An additional challenge for Mãori teachers is that there is an expectation that as they assume the role of a teacher, they also become an advocate and spokesperson for Māori pupils and communities (Fitzgerald, 2003a; Taukamo, 2011). Māori women educators can also be expected to be "change agents" to challenge existing structures in their educational organisations (Fitzgerald, 2003b, p. 7).

Fitzgerald (2003b) calls for us to challenge debates about gender and educational leadership to ensure that Pākehā women are not placed at the centre.

\section{Perspectives from Indigenous and ethnic minority women}

We found no literature on the experiences of Pacific women in Aotearoa New Zealand or the Pacific. Overall, there is a lack of research on Indigenous women in leadership internationally (Fitzgerald, 2003b; Robinson et al., 2019). Fitzgerald (2003b) describes this silence as "deafening", where "distinctions between and among women have collapsed in the attempt to provide a meta-narrative that describes and defines women's experiences and practices as educational leaders" (p. 2).

The literature we were able to find reiterates some of the barriers already discussed:

- The general tendency to apply stereotypes to leadership-in Western countries, leaders are white, male, heterosexual, middle class, middle aged. Those who diverge are "outsiders" (Coleman, 2012).

- Lack of mentorship and support, role models for Indigenous women, and networking opportunities (Jean-Marie, 2013; Robinson et al., 2019). In research focused on Asian-American women, women found it difficult approaching those with a higher status in the organisation as potential mentors. The authors suggest this may be due to a mixture of gender discrimination and violating the norms of being a "model minority"-a success story where individual efforts such as hard work and perseverance overcome racism (Liang et al., 2018).

- Difficulty in getting statistics about educational leadership, in relation to gender and ethnicity (Coleman, 2012).

Themes distinctive to the literature about Indigenous and ethnic minority women are:

- Intersectionality, acknowledging that dimensions of diversity provide a more complex picture, and Indigenous women walk and work in two systems (Coleman, 2012; Fitzgerald, 2003a).

- Narrowed opportunities, where ethnic minority school leaders are frequently appointed in urban areas, where the majority of students of colour are. The underlying assumption is that "minority school systems are the appropriate places for minority administrators" (Fitzgerald, 2003a, p. 10).

- Racial discrimination. Elton-Chalcraft et al. (2018) describe how Black and minority ethnic women in the United Kingdom experience subtle acts of discrimination and, when pursuing leadership roles, are told that they are "not ready yet" despite having the qualifications and years and of experience. Jean-Marie's case study saw African-American female principals also experiencing subtle racism from their own district leaders (Jean-Marie, 2013). In terms of programmes aimed towards developing leadership, there has been little attention given to structural inequalities and how it affects individual agency and leadership potential (Elton-Chalcraft et al., 2018). 


\section{Supports and enablers}

There is not as much research material on supports and enablers for women to take secondary school leadership roles, although the areas that need to be addressed are evident in the material on barriers in the previous section.

Most of the direct evidence on supports and enablers is qualitative, and mostly focuses on women leaders reflecting on how they made the journey and sustain their role, and researchers building on those reflections.

There are five key supports and enablers identified in the research reviewed. These range from the structural to the personal.

- Unbiased promotion and appointment processes

- Principals and other school leaders who actively develop, encourage, and mentor, and who open up opportunities and networks for women

- Creating more flexible principal roles

- Women's own planning and initiative, and the availability of appropriate leadership professional development

- Partners or friends who provide practical and emotional support.

\section{Unbiased promotion and appointment processes}

The impact of the Promotion of Women Review in the 1980s shows the importance of ensuring that the processes of promotion and appointment are not biased against women. Court (1994) found that job advertisements were also important: including the sentence "Applicants must demonstrate a commitment to equity in education and equal employment opportunities" attracted applications from 15 women and nine men, when the median number of applications for the role at the time was one woman and 14 men. In a tertiary context, Airini et al. (2011) highlights the university environment as one of five enablers for women's advancement. This includes policies and practices, and the application of these to individuals.

\section{Active support and mentoring from principals and other school leaders}

Principals and other school leaders who support and mentor women, developing their confidence as well as capability, and who give them opportunities to take responsibility, are a key support. Coleman (2007) found that $75 \%$ of the women leaders indicated that their previous headteacher was the most important person supporting them. Airini et al. (2011) analysing survey data from women in New Zealand universities also identified supportive relationships with senior colleagues as a key enabler for women's career progression.

Multiple articles identified that both male and female principals have enabled women to go further than the women would have initially envisaged (Alberta Teachers' Association, 2020; Cunneen \& Harford, 2015; Guihen, 2019; Mortimer \& Edwards, 2018; Smith, 2011b; Watterston, 2010). Campos-García and ZúñigaVicente (2019) cite other studies showing women principals "sponsor" and promote more women teachers to school leadership roles. 
Acting in the principal's role gave some women valuable positive feedback from their colleagues, and confidence in their leadership capabilities (Mortimer \& Edwards, 2018; Watterston, 2010). Others mention the assurance gained in leadership roles within the school from their colleagues' positive feedback and belief in them as a leader (Guihen, 2019). Watterston (2010) suggests demystifying leadership roles through work shadowing, or opportunities to "act up", including gaining insight into school governance.

Some women mentioned the unintended spur they got from experiencing poor leadership, and thinking they could do better (Guihen, 2019; Mortimer \& Edwards, 2018).

To better embed supports in the system, Spiller (2013) recommends that principals be required to report on their work to encourage, mentor, and support women into leadership roles, particularly principalship.

\section{Creating more flexible principal roles}

Co-principalship was positive for women, reducing their workload, isolation in the role, and improving their ability to balance work and family responsibilities (Eckman \& Kelber, 2010). Flexible headteacher roles were more favoured by women than men in England (McNamara et al., 2010).

\section{Women's own planning and initiative, and the availability of appropriate leadership professional development}

Women who succeeded in gaining principal roles noted the importance of: looking for and being given opportunities for leadership (Gallagher, 2017; Helterbran \& Rieg, 2004; Taukamo, 2011); training and formal study (Alberta Teachers' Association, 2020; Taukamo, 2011); networking, particularly with other women leaders (Gallagher, 2017); and ongoing mentor relationships.

Spiller (2013) draws from her own and others' experiences to recommend women positioning themselves through a careful choice of conferences and committees that allow the development of experience and credibility, contacts and networks, finding a strong mentor, and tackling the challenges of combining leadership and family by "frontloading" career development before having children.

Maunder and Warren (2008), cited in Watterston (2010), emphasise the value of networking and activities specifically focused on women to develop their confidence, capabilities, and support. Hearing from successful women principals also gives assurance about how to balance responsibilities. Watterston (2010) also encourages mutual support among women interested in school leadership, building "partnerships on the journey".

In a tertiary context, Airini et al. (2011) also highlight proactivity, with women taking planned courses of action with a view to advancement, and also taking a spontaneous course of action when opportunities arise (e.g., professional learning opportunities).

\section{Support and encouragement from partners and other family}

Partner and family support is also often mentioned by women who have become principals (Cunneen \& Harford, 2015; Liang et al., 2018; Mortimer \& Edwards, 2018; Watterston, 2010). It can take the form of affirmation, sharing the domestic workload, and understanding the demands of the principal role. 


\section{Wāhine Māori perspectives}

Taukamo's (2011) analysis of interviews with four Māori women secondary school leaders highlights the following as enablers and supports:

- the contribution of strong Māori foundational guiding principles learnt from their upbringing

- organisational and planning skills developed through marae and family responsibilities

- a passion for working with Māori students

- using mentors, and seeking advice

- formal study

- family support

- looking out for opportunities, "having a go", and seeing rejection as an opportunity for learning.

\section{Perspectives from Indigenous and ethnic minority women}

Role models, mentors, and peer supports are identified as key enablers in literature about Indigenous and ethnic minority women. Robinson et al. (2019) shows the importance of cultural knowledge, models and mentors, and networking with other Indigenous educational leaders for Mi'kmaq women principals in Canada. These women credited their leadership role to the female Mi'kmaq role models and mentors they had. They challenged Eurocentric leadership practices that were used by previous principals and viewed leadership as a shared responsibility.

Jean-Marie (2013) shows the importance of mutual support and shared spirituality for two Black principals encountering sexism and racism in a district of the United States.

Liang et al's (2018) study of pathways of Asian American women to school leadership found that encouragement from families, colleagues, and friends resulted in the women recognising their own administrative and leadership potential. Minority women who had mentors who were also minority women had greater trust in the relationship because of their shared experiences (Liang et al., 2018). 


\section{Looking ahead}

This short report provides an overview of the research literature on barriers and supports for women to succeed in secondary school leadership. The intention is that it will help the PPTA to shape future work to address gender-based inequities, and contribute to a goal where women are represented in secondary school leadership in the same proportion as their representation in the secondary school teaching workforce. Looking back at historical data suggests that Aotearoa New Zealand is unlikely to achieve gender equality in secondary leadership in the foreseeable future unless there is deliberate attention paid to the development and support of women as leaders in secondary schools.

As we noted earlier in the report, the issue of women being under-represented in secondary school leadership is long-standing, both in Aotearoa New Zealand and internationally. It is also not unique to secondary schooling, or to education. Brower and James (2020) conclude that the gender gap in universities will not disappear unless hiring practices change. Using this analysis as a catalyst, Jo Cribb (a former Chief Executive of the Ministry for Women) wrote an opinion piece that outlined what could make a difference for gender equity in the workplace. She calls for organisations to collect good data about what is actually happening (e.g., gender and ethnic pay gaps, who gets promoted and how long it takes, analysis of shortlists, and who gets other opportunities such as travel and conferences). Reporting and analysing this data can form the basis of an action plan, where "little steps are expected of lots of people" (Cribb, 2020, p. A19).

We identify a gap in national level data about the gender of school leaders, where data about positional leadership roles (other than the principal) is not readily available from the Ministry of Education. Good statistics are needed to track progress.

Our small survey gave a partial picture and served as a pilot if such an exercise were to be repeated. Two things to consider are: (a) how easy it is for a school principal or administrator to provide information about the gender of staff, by role; and (b) how to frame communication with principals so that it is the call for information is not seen as being targeted at female principals. We understand that to get a fuller picture, the PPTA intends to survey its women members about the leadership roles they occupy, and their interest in leadership roles, alongside their thoughts on barriers to taking on leadership roles that they have experienced, and the supports that make a difference. Information on ethnicity, gender status, and disability will also be able to be collected, bringing an important focus on intersectionality and dimensions of diversity.

This report has summarised key barriers and enablers to increasing the number of women in secondary school leadership roles. Across different countries there was a general consistency in the nature of barriers and supports identified. References to previous studies also show that most of these barriers and many of the supports are long-standing. Some supports are more recent, such as: specific programmes or networks for women; changes to recruitment, shortlisting, and appointment processes; providing options such as co-principalships; and greater emphasis on leadership practices that are more collaborative than hierarchical, and that develop collective learning cultures amongst school staff. 
Reaching a critical mass of women leaders calls for an approach that is enacted at all levels of the education system: by policy and regulation, by the Ministry of Education and other national bodies, in schools, and by individual women. Key enablers include strengthening mentoring and professional learning for women leaders and aspiring leaders, building mentoring of women explicitly into job roles, identifying talent early, and actively providing opportunities to build confidence and capability in potential leaders, along with ensuring that appointment processes are gender-neutral. Co-leadership roles and flexible working hours warrant investigation. A system strategy that has clear goals to tackle the under-representation of women in secondary school principalship and other positional leadership roles is likely to be needed.

The supports that enable Indigenous and ethnic minority women to take on leadership roles have some differences from those of majority groups. In an Aotearoa New Zealand context, any approach that aims to foster wāhine Māori and Pacific women's leadership needs to be cognisant of this and have different strategies that address structural barriers-for example, fostering connections with iwi, hapū and marae, and Pacific communities to develop strategies for identifying and supporting leaders.

We hope this report helps to put a focus on women in school leadership, and that it supports the PPTA to shape its work to effectively address gender-based inequities. 


\section{References}

Alberta Teachers' Association. (2020). Women in educational leadership needs assessment survey: An Alberta Teachers' Association research project. Author. https://www.teachers.ab.ca/SiteCollectionDocuments/ ATA/Publications/Research/COOR-101-28\%20Women\%20in\%20Educational\%20Leadership\%20Needs\%20 Assessment\%20Survey.pdf

Airini, Collings, S., Conner, L., McPherson, K., Midson, B., \& Wilson, C. (2011). Learning to be leaders in higher education: What helps or hinders women's advancement as leaders in universities. Educational Management Administration \& Leadership, 39(1), 44-62. https://doi.org/10.1177/1741143210383896

Blackmore, J., Thomson, P., \& Barty, K. (2006). Principal selection: Homosociability, the search for security and the production of normalized principal identities. Educational Management Administration \& Leadership, 34(3), 297317. https://doi.org/10.1177/1741143206065267

Bonne, L., \& MacDonald, J. (2019). Secondary schools in 2018: Findings from the NZCER national survey. New Zealand Council for Educational Research. https://www.nzcer.org.nz/system/files/NZCER_Nat-Survey-Report-Secondary. pdf

Brooking, K., Collins, G., Court, M., \& O’Neill, J. (2003). Getting below the surface of the principal recruitment 'crisis' in New Zealand primary schools. Australian Journal of Education, 47(2), 146-158. https://doi. org/10.1177/000494410304700204

Brower, A., \& James, A. (2020). Research performance and age explain less than half of the gender pay gap in New Zealand universities. PLOS ONE, 15(1), e0226392. https://doi.org/10.1371/journal.pone.0226392

Campos-García, I., \& Zúñiga-Vicente, J.A. (2019). The impact of a leader's demographic and professional characteristics on employee motivation: Do they really matter? Employee Relations, 41(1), 119-141. https://doi. org/10.1108/ER-10-2017-0253

Coleman, M. (2007). Gender and educational leadership in England: A comparison of secondary headteachers' views over time. School Leadership \& Management, 27(4), 383-399. https://doi.org/10.1080/13632430701562991

Coleman, M. (2012). Leadership and diversity. Educational Management Administration \& Leadership, 40(5), 592-609. https://doi.org/10.1177/1741143212451174

Court, M. (1994). 1893-1993: How far have we come in women's employment in education? New Zealand Annual Review of Education, 3, 81-128. https://www.wgtn.ac.nz/education/research/nzaroe/issues-index/1993/pdf/textcourt.pdf

Cribb, J. (2020, January 28). Jo Cribb: Institutional sexism and bias resolutely reside in academia. NZ Herald, A19.

Cunneen, M., \& Harford, J. (2015). Gender matters: Women's experience of the route to principalship in Ireland. In K. Fuller \& J. Harford (Eds.), Gender and leadership in education: Women achieving against the odds (pp. 147-174). Peter Lang.

Eckman, E. W., \& Kelber, S. T. (2010). Female traditional principals and co-principals: Experiences of role conflict and job satisfaction. Journal of Educational Change, 11(3), 205-219. https://doi.org/10.1007/s10833-009-9116-z

Education Council. (2018a). The Leadership Strategy for the teaching profession of Aotearoa New Zealand: Enabling every teacher to develop their leadership capability. Author. https://teachingcouncil.nz/sites/default/files/ Leadership_Strategy.pdf

Education Council. (2018b). Educational Leadership Capability Framework. Author. https://teachingcouncil.nz/sites/ default/files/Leadership_Capability_Framework.pdf

Elton-Chalcraft, S., Kendrick, A., \& Chapman, A. (2018). Gender, race, faith and economics: Factors impacting on aspirant school leaders. Management in Education. https://doi.org/10.1177/0892020618788738

Fenwick, P., \& Whitcombe, J. E. (1982). Teacher career and promotion study. Department of Education.

Fitzgerald, T. (2003a). Changing the deafening silence of indigenous women's voices in educational leadership. Journal of Educational Administration, 41(1), 9-23. https://doi.org/10.1108/09578230310457402

Fitzgerald, T. (2003b). Interrogating orthodox voices: Gender, ethnicity and educational leadership. School Leadership \& Management, 23(4), 431-444. https://doi.org/10.1080/1363243032000150962 
Fuller, K. (2017). Women secondary head teachers in England: Where are they now? Management in Education, 31(2), 54-68. https://doi.org/10.1177/0892020617696625

Fuller, K., Cliffe, J., \& Moorosi, P. (2015). Women's leadership preparation within the senior leadership team. Planning and Changing, 46, 388-415.

Gallagher, K. (2017). Barriers to pursuing the role of head of school as perceived by female administrators in independent schools [Doctoral Dissertation, St John Fisher College, Rochester, New York]. https://fisherpub.sjfc. edu/cgi/viewcontent.cgi?article=1315\&context=education_etd

Graham, A., \& Smith, L. (1999). The role of deputy and assistant principals in the New Zealand secondary school: A collaborative administrative project submitted in partial fulfilment of the requirement for the degree of Master of Educational Administration [Master of Educational Administration, Massey University, Palmerston North]. https:// mro.massey.ac.nz/handle/10179/10712

Guihen, L. (2019). The career experiences and aspirations of women deputy head teachers. Educational Management Administration \& Leadership, 47(4), 538-554. https://doi.org/10.1177/1741143217751727

Helterbran, V. R., \& Rieg, S. A. (2004). Women as school principals: What is the challenge? Journal of Women in Educational Leadership, 2(1), 12-21. http://digitalcommons.unl.edu/jwel/107

Hunt Brown, L. E. (2004). Barriers to women in educational leadership roles in Montana [Doctoral Dissertation, Montana State University, Bozeman, College of Education, Bozeman, MT]. https://scholarworks.montana.edu/ xmlui/handle/1/8643

Jean-Marie, G. (2013). The subtlety of age, gender, and race barriers: A case study of early career African American female principals. Journal of School Leadership, 23(4), 615-639.

Kruse, R. A., \& Krumm, B. L. (2016). Becoming a principal: Access factors for females. Rural Educator, 37(2), 28-38. https://eric.ed.gov/?id=EJ1225317

Liang, J. G., Sottile, J., \& Peters, A. L. (2018). Understanding Asian American women's pathways to school leadership. Gender and Education, 30(5), 623-641. https://doi.org/10.1080/09540253.2016.1265645

McGrath, K. F. (2019). When female leaders outnumber men: The decline of male school principals in Australia. Journal of Gender Studies, 29(5), 604-612. https://doi.org/10.1080/09589236.2019.1642739

McNamara, O., Howson, J., Gunter, H., \& Fryers, A. (2010). No job for a woman? The impact of gender in school leadership. NASUWT.

Mestry, R., \& Schmidt, M. (2012). A feminist postcolonial examination of female principals' experiences in South African secondary schools. Gender and Education, 24(5), 535-551. https://doi.org/10.1080/09540253.2011.628926

Ministry of Education. (2020). Teacher numbers. Education Counts. https://www.educationcounts.govt.nz/statistics/ schooling/workforce/teacher-workforce

Morrison, N. (2018, April 12). White men are still over-represented in school leadership. Forbes. https://www.forbes. com/sites/nickmorrison/2018/04/12/white-men-are-still-over-represented-in-school-leadership/

Mortimer, S. J., \& Edwards, F. (2018). Scaling the mountain to principalship in New Zealand: The enablers and barriers in a female principal's journey. In R. McNae \& E. C. Rielly (Eds.), Women leading education across the continents (pp. 60-65). Rowman \& Littlefield.

Oplatka, l., \& Tamir, V. (2009). 'I don't want to be a school head': Women deputy heads' insightful constructions of career advancement and retention. Educational Management Administration \& Leadership, 37(2), 216-238. https:// doi.org/10.1177/1741143208100299

Pearce, H. (2004). Making it to the top corridor: The struggle of New Zealand state secondary teachers to achieve a fair level of appointment to senior positions in co-educational schools after 1945 and to maintain it in girls' schools from the 1970s. Australia \& New Zealand History of Education Society Conference Proceedings, 78-85.

Pearce, H. (2015). Principals of all co-educational schools. PPTA.

Poole, G. (n.d.). Male school principals in short supply. Australian Men's Health Forum. https://www.amhf.org.au/_ male_school_principals_in_short_supply

Robinson, D. I. M., White, D. R. E., \& Robinson, D. D. B. (2019). Indigenous women in educational leadership: Identifying supportive contexts in Mi'kmaw Kina'matnewey. International Journal of Leadership in Education, 0(0), 1-21. https://doi.org/10.1080/13603124.2018.1562103

Smith, J. (2011a). Agency and female teachers' career decisions: A life history study of 40 women. Educational Management Administration \& Leadership, 39(1), 7-24. https://doi.org/10.1177/1741143210383900

Smith, J. (2011b). Aspirations to and perceptions of secondary headship: Contrasting female teachers' and headteachers' perspectives. Educational Management Administration \& Leadership, 39(5), 516-535. https://doi. org/10.1177/1741143211408450

Spiller, K. (2013). Preparing female leaders for the role of principal. Redress, 22(2), 6. 
Taukamo, T. (2011). 'He reka te wai o te hua pango: The darker the berry the sweeter the juice.' The experiences of Māori women in educational leadership in mainstream secondary schools. [Master's thesis, University of Waikato, Hamilton]. https://hdl.handle.net/10289/5595

Uwamahoro, J. (2011). Barriers to women in accessing principalship in secondary schools in Rwanda: A case study of two secondary schools in the Gicumbi District [Master's Thesis, University of the Witwatersrand, Johannesburg]. http://wiredspace.wits.ac.za/handle/10539/18808

Watterston, B. (2010). School leadership: Why a focus on women? Independent Education, 40(2), 24.

Watterston, B., \& Kise, J. (2019). Advice for aspiring female education leaders: Claiming voice through a both/and approach to gender. Australian Educational Leader, 41(3), 43.

"Women secondary school head teachers double in Wales in eight years". (2012, April 26). BBC News. https://www. bbc.com/news/uk-wales-17826267 


\section{Appendices}

\section{Appendix A: Survey of secondary and composite schools, June 2020}

PPTA has commissioned NZCER to do research on women in secondary school leadership positions. We have sent this survey to all secondary and area school principals to get an accurate national picture of the numbers of women in secondary school leadership roles. Your response will be anonymous and confidential to the NZCER researchers.

\section{Instructions}

If you are an area school, please only answer in relation to positions that cover secondary students (i.e., Year 9 and above). This may include positions that involve leadership across the wider school.

We are interested in people not full-time equivalents. An individual with more than one leadership role will be counted twice.

Please use the gender diverse category if you know that the person self-identifies as non-binary or gender diverse.

The survey is in four sections:

- Your school

- School-wide leadership

- Curriculum leadership

- Teacher/student support leadership

- Other leadership roles

\section{Your school}

1. Please provide your school Ministry of Education ID number. If you do not know it or do not have it to hand, please write your school name and nearest town.

2. How many teachers are there at your school (people not FTE)?

3. Please give the number of female, male, and gender diverse teachers at your school. [drop down box up to 100]

\section{School-wide leadership roles}

Please give the number of female, male, and gender diverse staff for each role in your school.

4. Principal [drop down box up to 2]

5. Associate Principal [drop down box up to 2]

6. Deputy Principal [drop down box up to 5]

7. Assistant Principal [drop down box up to 5] 


\section{Curriculum leadership roles}

Please give the number of female, male, and gender diverse staff for each role in your school.

8. Head of Department/Head of Learning Area/Faculty Leader [drop down box up to 20]

9. Teacher in Charge [drop down box up to 20]

\section{Teacher/student support leadership roles}

Please give the number of female, male, and gender diverse staff for each role in your school.

10. Deans [drop down box up to 10]

11. SENCO and other Special Education leaders [drop down box up to 5]

12. HOD Guidance/HOD Counselling [drop down box up to 5]

13. Specialist Classroom Teacher and Kāhui Ako roles - within school, and across school employed by the board [drop down box up to 10]

\section{Other leadership roles not covered above}

Please give the number of female, male, and gender diverse staff for each role in your school. 14.Other leadership roles not covered above and receiving management units. [drop down box up to 20] 

New Zealand Council for Educational Research

\section{๑ூேNZCER}

(f) facebook.com/nzcer

అ @NZCER

Rangahau Mātauranga o Aotearoa

in www.linkedin.com/company/new-zealandcouncil-for-educational-research 